\title{
Cytohormonal patterns in mature and pre-term babies
}

\author{
MARY CUMMINS, HARRY GORDON, ELIZABETH HUDSON, AND ERICA \\ WACHTEL
}

From The Institutes of Obstetrics and Child Health, Hammersmith Hospital, London W12, UK

SUMMARY Comparison of cytohormonal patterns in full-term and pre-term babies of both sexes showed significant differences. At birth, irrespective of gestational age, both groups had high oestrogen levels, reflecting the maternal hormonal environment, but whereas the mature neonates were capable of metabolising and excreting the excess hormone within the first week of life, the pre-term infants took much longer to do so. It is thought that immaturity or impairment of liver function is at least partially responsible for this finding.

Cytohormonal patterns are dependent on the type and concentration of circulating sex hormones. These cell patterns are readily demonstrable in vaginal aspiration smears, or in direct scrapes from the vaginal wall. The bladder epithelium reacts to hormonal stimulation in the same way as vaginal epithelium, and satisfactory samples for hormone assessment can easily be prepared from urinary sediment (Lencioni and Staffieri, 1969).

In the absence of sex hormone stimulation the responsive epithelium (vagina or bladder base) is thin and atrophic, consisting of only a few rows of round cells above the basement membrane-consequently smears from the vagina or from urine sediment contain large numbers of parabasal cells (Fig. 1). This is the situation throughout childhood until the menarche. Under the influence of oestrogenic hormones, the epithelium of vagina and bladder proliferates and matures to its full potential as a multilayered structure, with a clearly differentiated superficial layer. This is reflected in cytological preparations by the presence of large, flat, squamous cells with transparent cytoplasm and small, dark, structureless (pyknotic) nuclei (Fig. 2). In pregnancy, specimens usually contain large in termediate cells with thickened cell borders, a fine cytoplasm rich in glycogen, and eccentric vesicular nuclei (Fig. 3). These are referred to as navicular cells (Papanicolaou, 1925).

Smear patterns of newly born babies show a remarkably high degree of maturation and greatly

Received for publication 31 May 1978

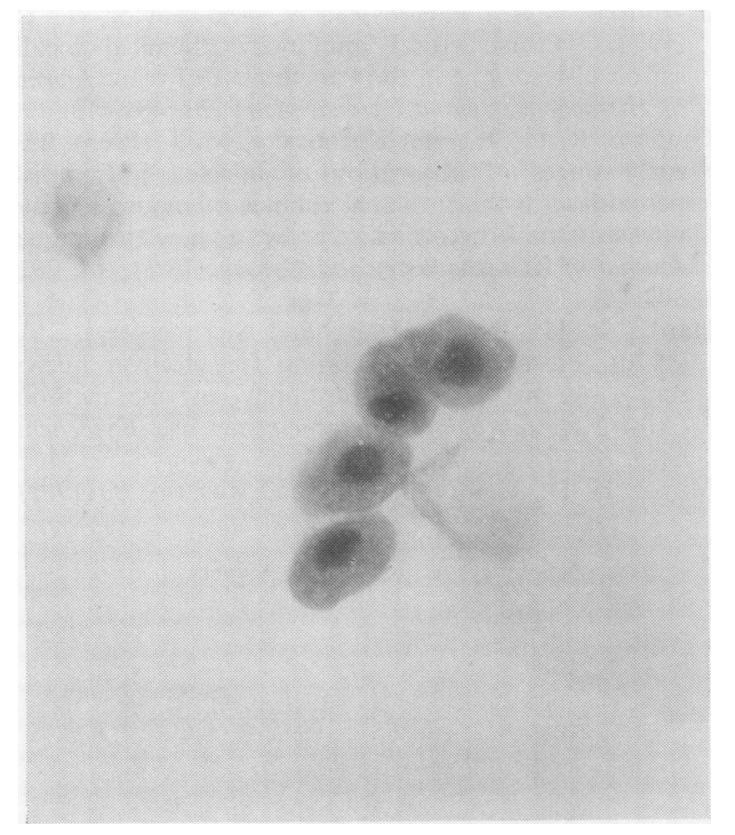

Fig. 1 Parabasal cells in urine sediment. Child aged 4 years. $\times 800$.

resemble the maternal pattern except that the karyopyknotic index (the percentage of superficial squamous cells) is higher in the baby (Wachtel and Plester, 1954). It is not really surprising that the cytological preparations are similar in the mother 


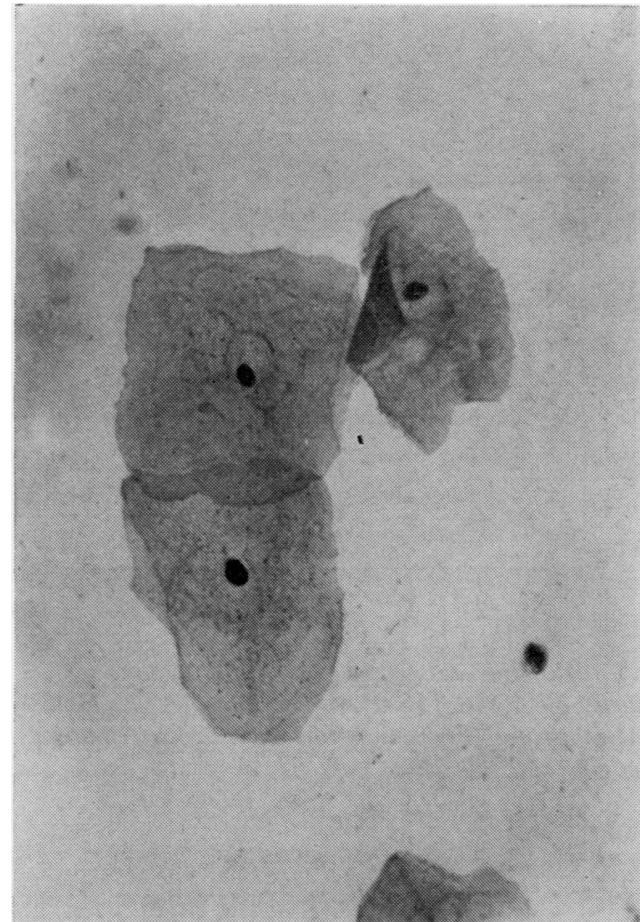

Fig. 2 Urine sediment, female infant aged 3 days. Squames with pyknotic nuclei. $\times 310$.

and neonate since both are exposed to the same hormonal environment. After birth, with metabolism and excretion of maternal oestrogen by the infant, the cytohormonal status changes and after a variable time atrophy is evident. Since hydroxylation of oestrone takes place in the fetal liver (Schwers et al., 1965; Gurpide et al., 1966; Zucconi et al., 1967; Hagen, 1970) metabolism might be delayed in babies with damaged or immature livers. This would result in the persistence of a high oestrogen pattern in such infants. This study was designed to test this hypothesis.

\section{Material and methods}

We studied 100 mature and 115 pre-term neonates. Urine samples were used for the determination of cytohormonal status in preference to vaginal smears in order that both male and female infants could be studied. Urine from mature infants was collected into sterile, purpose-made polythene bags, which were stuck to the perineum. That from pre-term infants was collected directly into universal containers without contact with the skin. The urine from

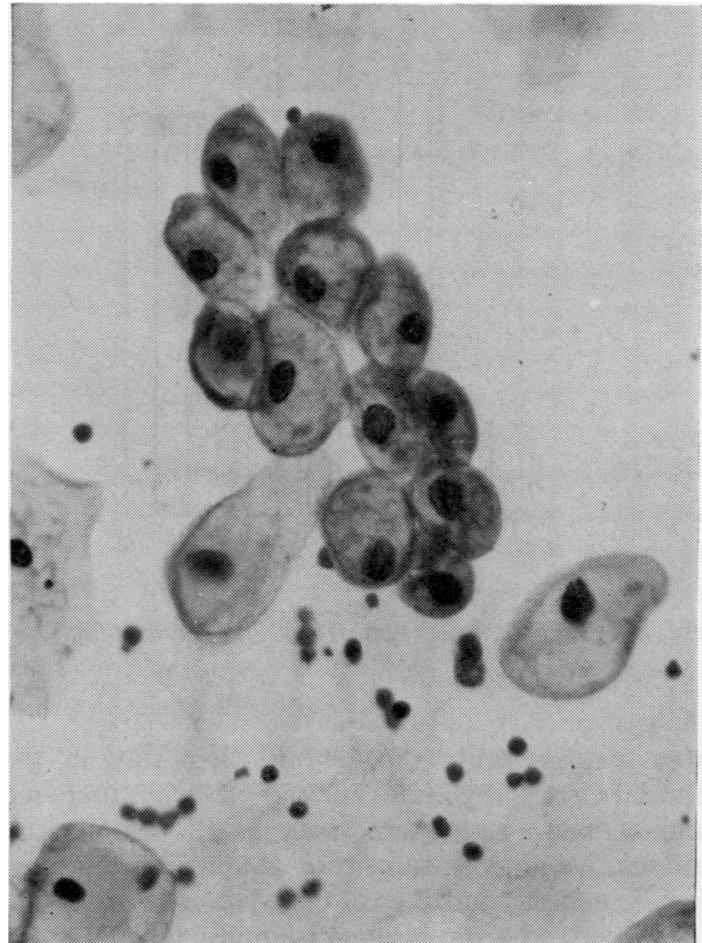

Fig. 3 Navicular cells in urine sediment. Pregnancy at term. $\times 650$.

the female infants may be contaminated with squamous cells from the genital tract; these reflect the hormone changes in the same way as the squamous cells from the urinary tract so their presence will not alter the results.

MATURE INFANTS

One hundred mature, new-born infants were examined; their maturity at birth was 38 or more completed weeks. Voided urine was obtained on day 1 or 2 and on alternate days thereafter until the baby left hospital (usually day 7 or 8). Urine samples were prepared using a cytocentrifuge (Shandon Elliot) and stained by the Papanicolaou technique. A minimum of 200 cells were counted. The karyopyknotic index and the percentage of parabasal cells were recorded.

\section{PRE-TERM INFANTS}

One hundred and fifteen pre-term infants were studied. Their maturity varied from 26 to 36 completed weeks of pregnancy (Fig. 4). Two sets of twins were included in this study. Urine samples were obtained within 72 hours of birth and there- 


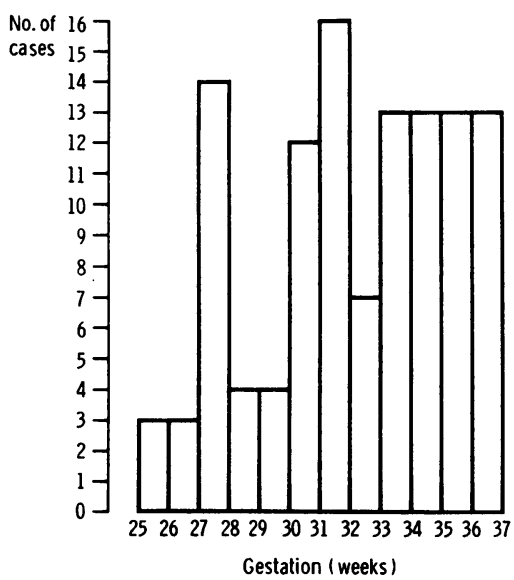

Fig. 4 Distribution of maturity, 115 pre-term infants.

after twice weekly throughout their stay in the Special Care Baby Unit. The samples were prepared and stained in the same way as for the mature infants. Vaginal smears were obtained from some female infants, and the results were compared with those derived from urinary samples taken on the same day. No significant differences were noted.

\section{Results}

Although the cytohormonal patterns of male and female infants were similar, the degree of cellularity varied markedly, many more cells being obtained in the urine voided by female infants. In most of the females it proved possible to count at least 200 cells, but a number of male samples had to be eliminated because there were too few cells to allow adequate assessment; furthermore, male urine samples contained many cells from the urethra, whereas in the female, squamous cells predominated. We included in our final analysis only babies who had provided at least two satisfactory samples.

\section{Term babies}

The decline in karyopyknotic index $(\mathrm{KI})$ for the infants in the first week of life is shown in Figs 5 and 6. Regression lines have been fitted using a logarithmic transformation to give appropriate representation to the data. The regressions were highly significant $\left(\mathrm{P}<10^{-6}\right)$. As the $\mathrm{KI}$ falls and atrophy develops, there is a rise in the percentage of parabasal cells (Figs 7 and 8 ). These observations relate to 40 male infants of maturity $39.9 \pm 0.8$ (SD) weeks and 38 females of identical maturity from

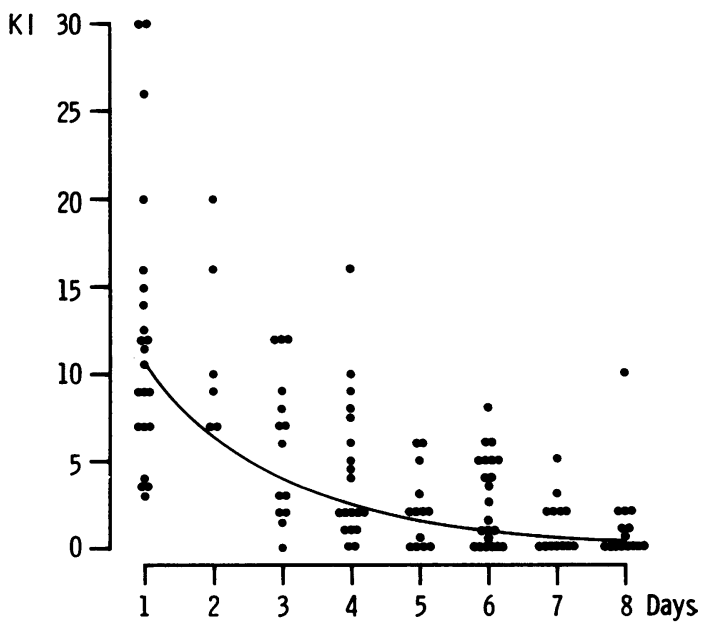

Fig. $5 \mathrm{KI}$ urine sediment 40 male infants days 1-8. Maturity $39.9 \pm 0.8(S D)$ weeks. Birth weight $3660 \pm$ 443 (SD) grams. Regression based on log distribution. Significance of regression $\mathrm{P}<10^{-9}$.

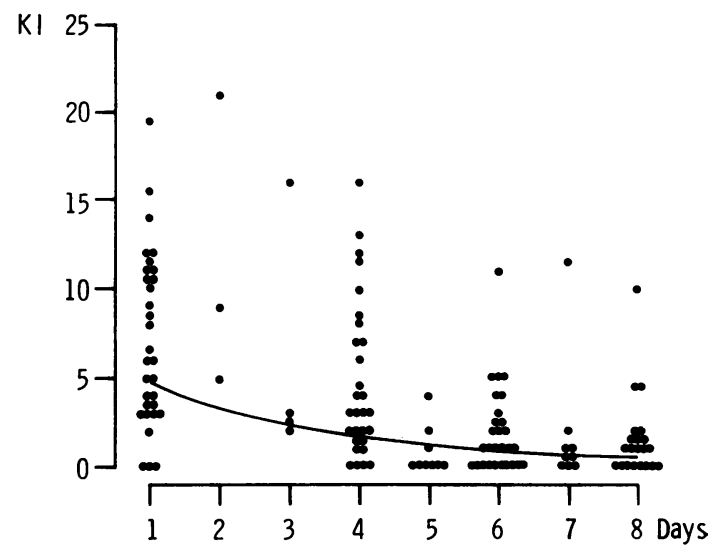

Fig. 6 KI urine sediment 38 female infants days 1-8. Maturity $39 \cdot 9 \pm 0 \cdot 8(S D)$ weeks. Birth weight $3370 \pm$ $456(S D)$ grams. Log regression-significance of regression $\mathrm{P}<10^{-9}$.

whom adequate samples had been obtained. Data from male and female infants are presented separately, though meaningful differences in $\mathrm{KI}$ and the percentage of parabasal cells (PB) were not demonstrable.

PRE-TERM BABIES

No statistically significant differences were detected between values for KI or per cent PB between pre- 


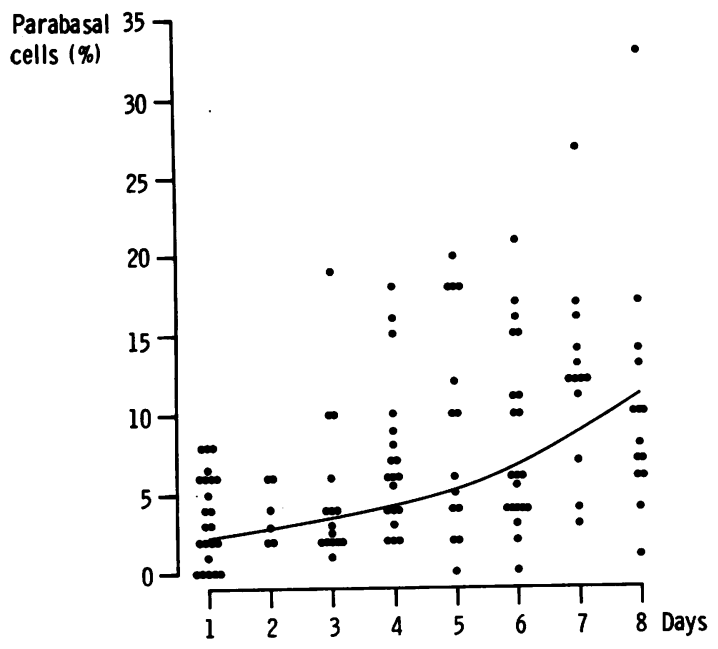

Fig. 7 Percent parabasal cells in urine sediment, 40 mature male infants. Logarithmic regression-significance $\mathbf{P}<10^{-6}$.

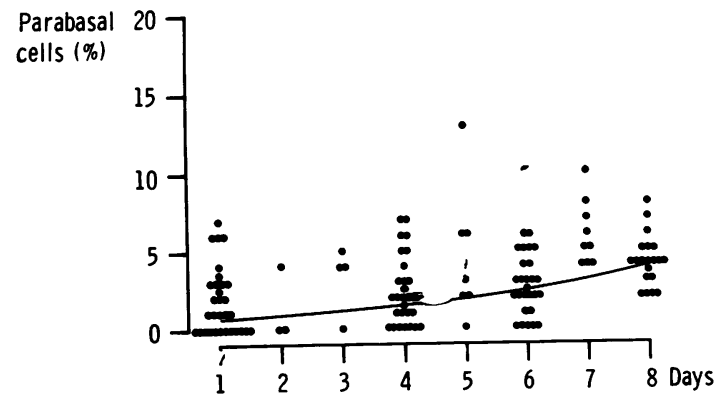

Fig. 8 Percent parabasal cells in urine sediment, 38 mature female infants. Log regression-significance $\mathrm{P}<10^{-6}$.

term babies born at 28-32 weeks' maturity and those between 33 and 36 weeks. Accordingly, pre-term babies born between 28 and 36 weeks of pregnancy were compared with the term babies. There was a considerable wastage in the premature group due to death, discharge from the special care unit, and a relatively high incidence of inadequate samples. The analysis was based on 13 male and 16 female preterm neonates for whom adequate serial data were obtained. Figures 9 and 10 show logarithmic regression lines based on data from those infants. Over the first week of life, in male babies the KI falls more slowly in pre-term babies than in term babies (difference in slopes, $P<0.05$ ). The percentage of parabasal cells rises more slowly in the

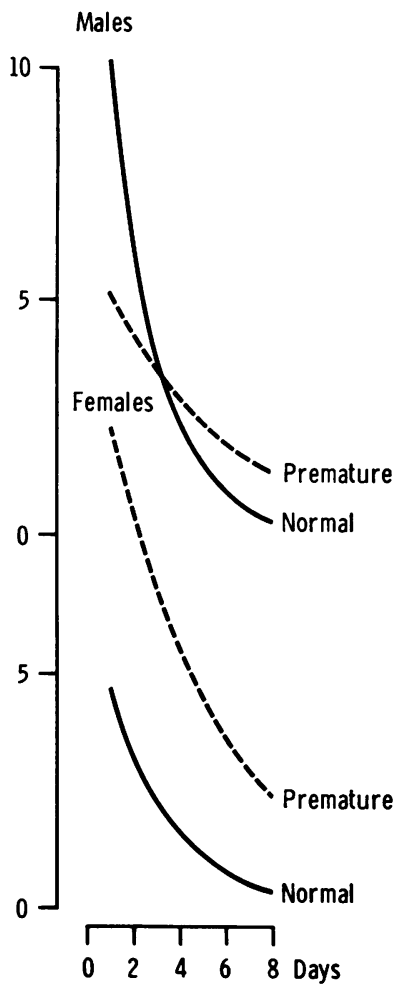

Fig. 9 KI in urinary sediment, term and pre-term infants. The male babies show a significantly slower decline. Difference in slopes $\mathrm{P}<0.05$.

first week of life in pre-term babies compared with those at term, the difference in slopes being significant $(P=0.05)$ in the females.

The range of karyopyknotic index and the percentage of parabasal cells in term and pre-term babies are shown in Tables 1 and 2. These data confirm that the KI falls more slowly and the per cent PB rises more slowly in premature babies. It will be seen that some pre-term babies show peristent oestrogen effects throughout the first 8 weeks of life. In one pre-term baby at 32 weeks' gestation, after an initial decline of $\mathrm{KI}$ a sharp rise coincided with the development of jaundice.

\section{Discussion}

The results presented support our hypothesis that oestrogen excretion is delayed in pre-term infants. Biochemical studies of oestrogen excretion in normal term infants carried out in Finland (Heikkilä, 1972) have shown that the concentration of oestriol and $15 \alpha$ hydroxyoestriol falls rapidly after delivery. The 


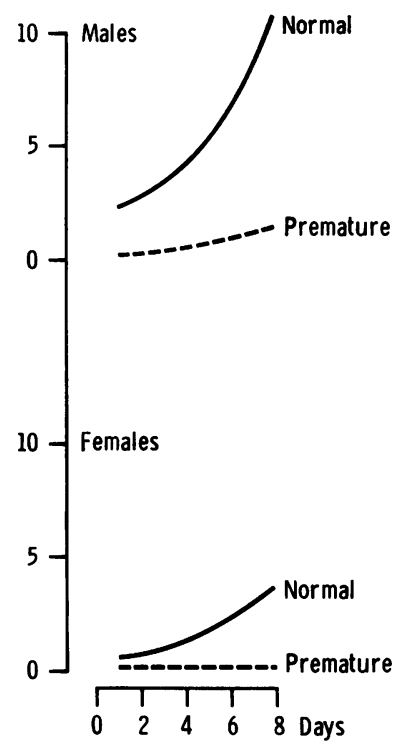

concentration of $15 \alpha$ hydroxyoestriol was relatively higher than oestriol, but both values become undetectable between days 4 and 5 . These findings are in keeping with our cytological results. Reynolds and his co-workers (1977) studied pre-term infants and showed that while initial serum oestriol values on the first day of life showed no difference with gestational age, decline curves were significantly slower in pre-term babies and seem to be related to the degree of maturity. Because cytohormonal study identifies the presence of any substance having an oestrogen effect, it has some advantage over more precise biochemical studies of individual oestrogens.

We are aware that there may be other causes for the delay in clearance of excess hormones, such as inefficient renal clearance. To attribute an important

Fig. 10 Percentage parabasal cells in urine sediment, mature and pre-term infants. The percentage of parabasal cells rises more slowly in the pre-term infants. The difference in slopes is significant in the females $(\mathbf{P}=0 \cdot 05)$.

Table 1 Median values of $K I$ in the neonatal period: ranges and numbers of observations in parentheses

\begin{tabular}{|c|c|c|c|c|}
\hline \multirow[t]{2}{*}{ Babies } & \multicolumn{4}{|l|}{ Day } \\
\hline & 1 to 3 & 7 and 8 & 25 to 30 & 45 to 52 \\
\hline \multicolumn{5}{|l|}{ Males } \\
\hline Mature & $\begin{array}{l}9 \cdot 0(0-30) \\
(41)\end{array}$ & $\begin{array}{l}0.0(0-10) \\
(28)\end{array}$ & - & 一 \\
\hline Pre-term & $\begin{array}{l}4 \cdot 0(0-14 \cdot 5) \\
(11)\end{array}$ & $\begin{array}{l}2 \cdot 0(0-4) \\
(7)\end{array}$ & $\begin{array}{l}0 \cdot 0(0-7 \cdot 5) \\
(12)\end{array}$ & $\begin{array}{l}1.0(0-3) \\
(10)\end{array}$ \\
\hline Difference (Wilcoxon test) & NS & NS & - & - \\
\hline \multicolumn{5}{|l|}{ Females } \\
\hline Mature & $\begin{array}{l}6 \cdot 0(0-21) \\
(38)\end{array}$ & $\begin{array}{l}1 \cdot 0(0-10) \\
(30)\end{array}$ & - & - \\
\hline Pre-term & $\begin{array}{l}11 \cdot 5(0-15 \cdot 5) \\
(18)\end{array}$ & $\begin{array}{l}5 \cdot 0(0-12 \cdot 5) \\
(12)\end{array}$ & $\begin{array}{l}2 \cdot 0(0-8) \\
(17)\end{array}$ & $\begin{array}{l}2 \cdot 0(0-7) \\
(10)\end{array}$ \\
\hline Difference (Wilcoxon test) & $P<0.05$ & $P<0.05$ & - & - \\
\hline
\end{tabular}

Table 2 Median values of percent $P B$ in the neonatal period: ranges and numbers of observations in parentheses

\begin{tabular}{|c|c|c|c|c|}
\hline \multirow[t]{2}{*}{ Babies } & \multicolumn{4}{|l|}{ Day } \\
\hline & 1 to 3 & 7 and 8 & 25 to 30 & 45 to 52 \\
\hline \multicolumn{5}{|l|}{ Males } \\
\hline Mature & $\begin{array}{l}3 \cdot 0(0-10) \\
(43)\end{array}$ & $\begin{array}{l}11 \cdot 0(1-27) \\
(28)\end{array}$ & 一 & - \\
\hline Pre-term & $\begin{array}{l}0.0(0-5) \\
(13)\end{array}$ & $\begin{array}{l}2 \cdot 0(0-4) \\
(8)\end{array}$ & $\begin{array}{l}4 \cdot 0(0-11) \\
(10)\end{array}$ & $\begin{array}{c}4 \cdot 0(2-22) \\
(9)\end{array}$ \\
\hline Difference (Wilcoxon test) & $P<0.01$ & $P<0.01$ & - & - \\
\hline \multicolumn{5}{|l|}{ Females } \\
\hline Mature & $\begin{array}{l}1.0(0-6) \\
(38)\end{array}$ & $\begin{array}{l}4 \cdot 0(2-50) \\
(31)\end{array}$ & - & - \\
\hline Pre-term & $\begin{array}{l}0 \cdot 0(0-8) \\
(18)\end{array}$ & $\begin{array}{l}0.0(0-11) \\
(9)\end{array}$ & $\begin{array}{l}8 \cdot 0(0-23) \\
(19)\end{array}$ & $\begin{array}{l}8 \cdot 5(2-53) \\
(10)\end{array}$ \\
\hline Difference (Wilcoxon test) & $P<0.01$ & $P<0.05$ & - & - \\
\hline
\end{tabular}


role to the liver is, however, tempting, especially in view of the observation on a pre-term baby in this study of a rising karyopyknotic index after an initial fall when the baby became jaundiced, the rise persisting until the jaundice subsided.

The biochemical effects of prolonged exposure to maternal oestrogen in the neonatal period have not been studied but presumably they must exist. There should, for example, be effects on protein binding, though these may not be of clinical significance. Cytological evidence of persistent oestrogen effects may indicate impaired hepatic function and serial urinary cytohormonal assessments may provide a simple method of assessment of hepatic maturity in the neonate.

We thank the nursing staff of the Maternity Unit of the Royal Berkshire Hospital, Reading and its associated general practitioner units who collected the specimens from the full-term infants.

The urines of the pre-term infants were collected in the Special Care Baby Unit of The Hammersmith Hospital and we are very grateful to the nursing staff for the extra work this entailed. We also thank Mr D. F. Hawkins for his encouragement and helpful criticism.

\section{References}

Gurpide, E., Schwers, J., Welch, M. T., Vande Wiele, R. L., and Lieberman, S. (1966). Fetal and maternal metabolism of estradiol during pregnancy. Journal of Clinical Endocrinology, 26, 1355-1365
Hagen, A. A. (1970). Formation of $15 a$ hydroxyestriol from $4-{ }^{14} \mathrm{C}-17$ beta estradiol and $6,7-{ }^{3} \mathrm{H}$ estriol by an anencephalic. Journal of Clinical Endocrinology, 30, 763-768.

Heikkilä, J. (1972). Excretion of $15 \alpha$ hydroxyoestriol and oestriol in urine of newborn infants and in maternal urine before and after delivery. Journal of Endocrinology, 52, 119-128.

Lencioni, L. J., and Staffieri, J. J. (1969). Urocytogram diagnosis of sexual precocity. Acta Cytologica, 13, 382-388.

Papanicolaou, G. N. (1925). The diagosis of early human pregnancy by the vaginal smear method. Proceedings of the Society of Experimental Biology and Medicine, 22, 436-437.

Reynolds, J. W., Bentley, K., and Turnipseed, M. R. (1977). Serum total estriol in abnormal newborn infants. Journal of Steroid Biochemistry, 8, 853-858.

Schwers, J., Eriksson, G., and Diczfalusy, E. (1965). Metabolism of oestrone and oestriol in the human foeto-placental unit at midpregnancy. Acta Endocrinologica, 49, 65-82.

Wachtel, E., and Plester, J. A. (1954). Hormonal assessment by vaginal cytology. Journal of Obstetrics and Gynaecology of the British Empire, 61, 155-161.

Zucconi, G., Lisboa, B. P., Simonitsch, E., Roth, L., Hagen, A. A., and Diczfalusy, E. (1967). Isolation of $15 a$-hydroxy-oestriol from pregnancy urine and from the urine of newborn infants. Acta Endocrinologica, $56,413-423$.

Requests for reprints to: Harry Gordon, FRCS, FRCOG, Obstetrics Department, Northwick Park Hospital, Watford Road, Harrow, Middlesex HA1 3UJ, UK. 